\title{
O CRISTÃO ENTRE O EVANGELHO E A CONCORRÊNCIA
}

\author{
† António Monteiro \\ Bispo de Viseu
}

O homem, seja ele quem for, no dizer bem conhecido de Ortega Y Gasset, é sempre e necessariamente o homem e a sua circunstância. É a questão importante, da interacção radical entre o homem e o seu ambiente.

Num mundo invadido pela concorrência, frequentemente desenfreada, tal contexto mexe necessariamente com todo e qualquer homem e, muito em especial, com os seus comportamentos. Sucede isso também com o cristão, muito embora ele tenha o evangelho como o grande ideal e programa de base na sua vida. A influência de um tal contexto ambiental converte-se, a partir daí, num problema, por vezes dramático, nomeadamente quando esse contexto revela uma dinâmica em contradição frontal com a dinâmica do evangelho. É o caso certamente da dinâmica concorrencial. Num ambiente assim, o cristão terá por vezes de fazer opções muito sérias, opções daquelas que, na expressão de Kierkegaard, ele tem de afrontar em clima de angústia, de vertigem metafísica, com temor e tremor, armado sempre e só em cavaleiro da fé.

É o tal problema do cristão situado num mundo de concorrência que aqui vou analisar.

Exporei sumariamente os seguintes aspectos que se prendem com o presente problema, nomeadamente os seguintes: o contexto concorrencial em que hoje vivemos, os limites do modelo concorrencial, as consequências da concorrência, sobretudo a nível moral, a perspectiva evangélica no seu contraste com a concorrência e, a terminar, as atitudes ou opções que se impõem aos cristãos, a partir da sua vocação, num mundo invadido pela concorrência.

\section{O CONTEXTO CONCORRENCIAL DO NOSSO TEMPO}

A perspectiva concorrencial existiu sempre na vida do homem. Quase por instinto, o homem tende a sobrepor-se ao outro, a ser mais do que ele. É um dos chamados instintos de morte que vão em cada um de nós, na linguagem de S. Freud. Instinto de morte ou, talvez ainda melhor, instinto contra a morte. Há efectiva- 
mente, em cada homem, uma visão instintiva do outro como eventual inimigo, alguém que pode pôr em risco a sua vida, alguém que pode ser um obstáculo para o seu crescimento e que, por isso mesmo, facilmente começa a ver-se como inimigo a abater. Quando Sartre dizia que o inferno são os outros, ia um pouco na linha desta convicção. Na própria Bíblia, o primeiro pecado do mundo parece ter tido a sua origem nesta dinâmica concorrencial. A serpente original aparece ali a propor ao homem a concorrência com o único outro do homem, então existente, que era o próprio Deus. Propôs-lhe simplesmente a serpente ser como Deus, lutando com Ele corpo a corpo. E o homem aceitou o desafio ${ }^{1}$.

Tal dimensão concorrencial foi tomando sempre diversas formas, ao longo da história, formas bem conhecidas, às quais ofereceu um bom ambiente o sistema capitalista, nomeadamente na sua forma mais escandalosa do capitalismo selvagem. O marxismo e o estalinismo estatizante opuseram-lhe certamente uma determinada barreira. Hoje, com a queda do marxismo e do seu sistema de cariz totalitário, tal espírito concorrencial voltou a atacar em força. É um dos tais efeitos do abuso de um dom tão grande como é o da liberdade, felizmente recuperada da parte de muitos povos. E aí está a concorrência a tomar sempre mais corpo no relacionamento entre pessoa e pessoa, grupo e grupo, nação e nação, bloco e bloco. Dá impressão que, nos seus intentos e programas, todos pretendem só e unicamente passar para a frente do outro, assegurar um posto mais elevado do que o outro, ser mais do que o outro, ganhar mais do que o outro, poder mais do que o outro. Começando pela linha do ser, passa-se logicamente para a linha do fazer, e sobretudo para a linha do ter. Uma tal concorrência aparece facilmente em todos os campos: no mundo da educação, da política, do desporto, da economia, no campo do saber, da investigação, nomeadamente quando se trata da investigação bélica, etc. Parece que não somos capazes de nos notabilizarmos, a não ser deixando atrás de nós um vencido, uma vítima. Para cúmulo, fazemos a história e depois escrevemo-la sem o mais elementar poder crítico e, se calhar, para nos justificarmos a nós próprios, chamamos heróis, levantamos estátuas a tantos que, para assegurarem esse lugar cimeiro, deixaram atrás de si montes de vítimas. Foram subindo os pódios à custa de todos aqueles que eles próprios destruíram. São assim muitos dos heróis que hoje imortalizamos. Com os seus nomes que deveriam ficar para sempre esquecidos, para desgraça da humanidade, carregamos a memória dos nossos jovens que, à luz dessas figuras, amanhã, vão continuar a fazer a história. O problema é ainda mais sério porque um tal sistema se converte num gravíssimo anestesiante das consciências para tantos crimes que se vão cometendo e tantas mortes que se vão sucedendo diariamente aos nossos olhos, até nas nossas estradas, onde até ali parece necessário mostrar que eu e o meu carro andamos mais depressa que todos os outros. O caso torna-se ainda mais terrificante quando esta concorrência, conduzida pela técnica, entra na produção dos meios de destruição, de devastação, de morte. Todos querem então ter armas 
mais fortes que as do adversário, que matem mais e mais depressa do que as armas do outro, com efeitos mais catastróficos que as do outro, que metam mais medo que as armas do que thes parece ser o seu concorrente. A partir daqui, as nações e os povos passam a valorizar-se pelo maior poder das suas armas e meios de destruição, pelos maiores arsenais atómicos ou nucleares de que disponham. Depois o pior é que ninguém se atreve a chamar nomes a essas nações, mesmo que elas estejam a gastar, em armas o dinheiro, a riqueza e os bens que dariam de comer a tantos esfomeados da terra, a milhares e milhares de crianças que todos os dias morrem de fome por esse mundo além.

A concorrência invadiu de facto o nosso quotidiano e nele os meandros do nosso ser, de todo o nosso existir.

Não se pode negar, entretanto, que o tal fenómeno da concorrência tem feito crescer muita gente. Tem sido factor de progresso, um caminho para sermos mais, para termos mais. É necessário entretanto perguntarmo-nos seriamente a quantos e a quais a concorrência fez de facto crescer e ter mais. Sobretudo haverá que ter muito presentes as vítimas que uma semelhante concorrência deixou pelo caminho e concluir depois, objectivamente se, de facto, se tratou de progresso ou de retrocesso, se foi crescimento ou foi antes só uma "inchação", na linguagem do escritor brasileiro.

Vêm aqui os limites do processo concorrencial que agora queria analisar.

\section{LIMITES DO SISTEMA CONCORRENCIAL}

Antes de mais, interessa ter presente o que aqui entendemos propriamente por concorrência.

Concorrência, neste nosso contexto, é a dinâmica, o sistema que pretende levar as pessoas a avançar e crescer sempre mais, aos vários níveis, só e unicamente pondo-se, situando-se à frente do outro, seja ele quem for, ultrapassando-o, deixando-o para trás.

Tal sistema, com a dinâmica que lhe é própria, sofre, entre outras, de três ambiguidades, defeitos ou limites que o põem, liminarmente, em questão, ambiguidades que aqui aponto sumariamente.

Antes de mais, é um sistema que aparece logo como imoral pelo facto de pretender só ultrapassar, passar por cima do concorrente, sem sequer se pôr a questão se, ao fazê-lo, está a actuar bem ou mal. Aquilo que visa o que actua, segundo o sistema concorrencial, é pôr-se à frente do outro. Passar à frente do outro, ainda que para isso tenha de se expor à morte, ele próprio ou os outros. Pensemos na manifestação concreta e simples de uma ultrapassagem na estrada. É uma forma de concorrência. De um exemplo tão simples e comezinho, poderfamos passar, a título de exemplo, à concorrência no contexto da corrida aos armamentos por 
parte das grandes potências. Tenta-se passar à frente de qualquer outra nação, mesmo que para isso fiquem populações inteiras sujeitas à fome, crianças a morrer aos montes ou descurados sectores importantes, tais como a saúde, a habitação, etc..

Para além desse aspecto, verificamos facilmente que o sistema concorrencial, na sua própria génese, funciona a partir de uma dinâmica voltada para a morte, para deixar o outro para trás, para o anular, quer se trate de pessoas, quer se trate de grupos. Mais do que crescer, actuar, aumentar, ser mais ele próprio, o que se pretende é anular o outro. Anular o outro, dimimuí-lo, impedi-lo de crescer, opôr-se-lhe, atitudes que, em última análise, são atentados directos, formas de liquidar a vida do semelhante. É uma forma de matar, de destruir o outro. Pode ser com uma morte violenta, que às vezes também acontece, como se vê com frequência; ou então com uma morte lenta que, por vezes, é ainda pior, pelo menos em certo sentido. No caso de uma morte violenta, para se sossegarem as consciências, é comum nomear-se a seguir uma comissão de inquérito e tudo fica por ali. $\mathrm{Na}$ morte lenta, nem isso se faz. Em qualquer dos casos, é sempre fazer uma coisa má, ainda que ela se intente para obter um fim considerado ou proposto como bom. Trata-se por isso sempre de um processo que redunda, em última análise, numa verdadeira iniquidade. É o tal maquiavelismo social.

Para além do que fica dito, o sistema concorrencial como tal é também estruturalmente injusto. Leva sempre consigo um certo sentido de injustiça. Seria justo de facto concorrer com outro se as pessoas fossem iguais em todos os aspectos. Sucede, porém, que é exactamente o contrário. Todos nós, como no-lo recorda acertadamente o Santo Padre João Paulo II na "Redemptor Hominis", somos uma realidade única e irrepetível ${ }^{2}$. Tal unicidade e irrepetibilidade atinge tudo o que há no homem, o seu ser e, consequentemente, também o seu actuar. Por isso nunca as pessoas podem concorrer ou concorrem em plano de igualdade, condição que seria essencial para se poder competir num quadro de justiça. É por aqui que o sistema da concorrência implica em si mesmo uma nota estrutural de injustiça contra o próprio semelhante. Por vezes, tal desigualdade é mesmo gritante. Entra pelos olhos dentro. Como é que, por exemplo, um país rico pode pôr-se a concorrer legitimamente com um país pobre? Como é que um filho de "papá", com uma fortuna atrás de si a defendê-lo e a apoiá-lo, pode pôr-se a concorrer, numa linha de justiça, com o filho de um pobre pai de família que vive e conta apenas com o seu dia a dia? Como é que uma empresa poderosa, com técnica sofisticada em todos os apectos, pode competir justamente com uma pequena empresa, porventura meramente familiar? Como é que qualquer pessoa, investida em autoridade e com crédito nos bancos e no mundo da finança, pode moralmente ir competir, em termos de justiça, com um anónimo qualquer a viver apenas do pão de cada dia? Admitir um tal sistema é o mesmo que aceitar a competição entre o lobo e o cor- 
deiro. É a partir daqui que o processo concorrencial é mesmo uma enormidade moral.

São estes, entre outros que aqui se poderiam apontar, os limites que acompanham e explicam as consequências morais do sistema concorrencial que agora vamos considerar.

\section{O SISTEMA CONCORRENCIAL E AS SUAS CONSEQUÊNCIAS NA VIDA MORAL}

Não se pode negar que a dinâmica concorrencial leva também consigo alguns aspectos positivos, aos quais já aludi. Entre eles, está sem dúvida o estímulo que promove no sentido da sobrevivência, estímulo que é evidentemente factor de progresso, aumento de riqueza, etc..

Entretanto, mesmo esse progresso e aumento de riqueza terão que ponderar-se bem, não esquecendo sobretudo a factura que levam consigo na linha dos aspectos negativos já referidos.

E vem aqui o significado das consequências morais, de sentido negativo do sistema concorrencial que passo a sublinhar.

Uma dessas consequências é o chamado fenómeno da amoralização que vai marcando sempre mais o mundo do nosso tempo. Tal fenómeno passa, como hoje se diz, por uma maior abundância de mal moral no mundo, facto que é inegável, como se pode comprovar todos os dias, até pelo que vai aparecendo na nossa comunicação social. Essa maior abundância de mal moral nos nossos dias é também certamente uma consequência sem dúvida dos meios de que o mal hoje dispõe, a todos os níveis. Mas, além de uma maior quantidade de mal moral, verifica-se igualmente que o mal, ao contrário do que sucedia em tempos passados, perdeu a clandestinidade de que então gozava. Havia uma certa vergonha de proceder mal. O mal existia, mas escondia-se. Mas, há ainda um outro aspecto a não esquecer que é novo. O mal é mais abundante, perdeu a sua clandestinidade, mas vai mais longe. Chegou mesmo a ser aceite com naturalidade e até se tem pretendido dar-lhe uma base, um suporte legal. As leis, que deveriam ser, pela sua própria definição, indicativos do bem, dos valores ${ }^{3}$, passam a ser indicativos, portas abertas, incentivos para o mal. Imaginemos que um dia as placas de trânsito, nas nossas estradas, em vez de indicar os caminhos certos pelos quais nos podemos conduzir salvos e seguros, passam a apontar abismos, precipícios e a apresentá-los como vias seguras. É o caso das leis que passam a dar suporte ao mal. Para além de tudo isso e ainda pior do que tudo isso, é que não se aceitam, recusam-se ou simplesmente não se consideram, marginalizam-se as normas que havia antes para nos apontar o bem, para nos defenderem dos perigos e até para podermos distinguir o bem do mal. Quer dizer, não se recusa apenas o mal. Recusam-se mesmo 
as normas fundamentais da moral. É como se, a nível da língua nacional, não só se dessem erros morfológicos ou outros da gramática, como tantas vezes infelizmente acontece, mas, liminarmente, se marginalizassem ou mesmo recusassem as próprias regras gramaticais. Não há dúvida que seria uma babilónia, um autêntico caos no mundo da comunicação. Pois é exactamente isso mesmo o que está a acontecer a nível da moral. Não se transgridem apenas, com a maior das naturalidades, as normas morais, mas recusam-se essas normas. Não se aceitam. Vem daí a tal babilónia, bem pior do que a babilónia linguística. É a babilónia moral que pode um dia tornar mesmo inviável a vida humana nesta terra. Uma vida, e mais ainda uma vida social sem regras, é inviável. Pois é isto mesmo o que se designa por amoralização, fenómeno típico do nosso tempo.

Há quem pense que um tal fenómeno, pelas consequências nefastas de que se reveste, pode ser mesmo um efeito da presença tenebrosa, da aç̧ão do demónio no mundo. Se calhar, pode vir daqui que hoje se fale tanto do demónio, de santanás, dos exorcismos e até de cultos satânicos, da devoção ao demónio, etc., etc..

O fenómeno da amoralização porém está longe de ter a sua explicação na presença do demónio no mundo, no sentido de qualquer ser extra-terrestre a interferir na vida dos homens. Muito menos podemos ou devemos pensar que esse fenómeno se resolve com exorcismos. Seria mais uma alienação, entre muitas que já temos.

Também a explicação não pode nem deve encontrar-se simplesmente a partir da maldade dos homens do nosso tempo, como outros pretenderiam dizer, partindo-se do princípio de que os homens de hoje seriam piores que os de outros tempos da história.

O fenómeno da amoralização é bastante mais complexo. Na sua origem, o fenómeno vai prender-se com uma série de factores com os quais convivemos muitas vezes pacificamente e em cuja génese todos podemos estar um pouco implicados. Pode verificar-se que venham a ser mais responsáveis e estejam mais implicados os que governam e presidem à sociedade em geral, mas a responsabilidade pode atingir-nos também um pouco a todos.

Os referidos factores são certamente múltiplos e complexos, como múltiplos e complexos são todos os fenómenos humanos, a qualquer nível. Neste campo, nunca há causas únicas. Pelo que à amoralização se refere, eu apontaria, entre os factores que estão na sua origem, os seguintes: a massificação das pessoas nas nossas cidades e com ela a pressão de umas sobre as outras, a desumanização do homem cada vez mais submetido e condicionado pela técnica, também cada vez mais sofisticada, pela máquina, pelo robot que aí está a chegar em força sem consciência, sem responsabilidade; a pressa, a agitação em que constantemente somos lançados por uma sociedade a despertar sempre novas fomes e novas sedes que dão sempre mais no homem unidimensional de Marcuse ${ }^{4}$, a tirania da publicidade estudada e bem orquestrada para nos conduzir numa direç̧ão bem determinada; a 
manipulação e os atentados constantes à liberdade e responsabilidade pessoal num tempo em que, paradoxalmente, se fala tanto liberdade; a coisificação do homem em apelos constantes, bem montados e apresentados a tudo que é meramente instintivo; a neutralização na vida humana da dimensão do belo, sem tempos de contemplação, de silêncio, etc.. São estes e outros fenómenos parecidos que, em grande parte, estão na génese desse fenómeno grave da amoralização do nosso tempo. Cada um deles merecia um aprofundado estudo e reflexão nesta perspectiva, para que todos fôssemos abrindo sempre mais os nossos olhos e interviéssemos, enquanto é tempo de salvarmos o homem, a sua dignidade, a sua felicidade, presente e futura.

É precisamente entre estes factores da amoralização que eu quero contar a concorrência e o seu sistema. Esta é efectivamente uma das consequências mais graves do processo concorrencial.

É facil compreender este efeito da dinâmica concorrencial. De facto, se qualquer pessoa, para sobreviver, tem de vencer o seu adversário, a nível de eficácia, de crescimento, de progresso económico, todas as regras da moral, toda a ética, no campo da justiça, da responsabilidade em geral têm necessariamente de se deixar de lado. Na melhor das hipóteses, todas as normas morais terão de passar e contar apenas no campo da utopia, uma vez que muitas delas são um obstáculo ao crescimento, ao progresso. Pensemos, para não ir mais longe nem recorrer a qualquer hipótese muito complicada, que o vizinho do lado deita água no vinho e eu não o quero fazer por imposição da minha consciência moral. É claro que o tal meu vizinho do lado vai poder vender o vinho mais barato do que eu e lá vão os meus clientes e eu, mais tarde ou mais cedo, terei de fechar as portas para evitar a minha total e inevitável bancarrota económica. É assim neste campo, tão simples e tão banal. Mas poderíamos passar daqui para o campo das grandes empresas. Ouvi dizer, há algum tempo, a um responsável do governo que são cerca de 200 milhões de contos os que as grandes empresas devem em Portugal à Segurança Social, por não pagarem os respectivos impostos, cujo montante é, pelos menos parcialmente, deduzido dos proventos que seriam devidos aos trabalhadores. É claro que tais empresas, com lucros que não lhes pertencem, podem vender os produtos mais baratos do que qualquer outro que cumpra o dever de pagar o que deve por justiça, para que os beneficiários da Segurança Social recebam o que lhes é devido. Em conclusão, se o critério for a luta pela sobrevivência, contra o mais forte, o que me pode esmagar, toda e qualquer moral tem de passar necessariamente, como já se disse, para o reino da utopia.

Trata-se apenas de uma ou outra aplicação em casos concretos. Poderia fảlar aqui, e na mesma linha, da falsificação das contas, da fraude fiscal nas diversas vertentes, do trabalho infantil, do salário injusto, dos despedimentos sem justa causa, dos trabalhos a prazo sem motivo, etc. etc.. Se a lei é a concorrência, vale tudo. Vale até cortar porventura os dedos das mãos aos outros, como se diz terem 
feito os colonizadores ingleses ao chegarem ao Bangladesh. Encontraram lá teares primitivos e muito simples de que dispunha aquela gente, mas que lhes permitiam produzir tecidos que iriam dispensar as exportações pretendidas pela Inglaterra na mira de um novo campo de mercado. É isso a concorrência, na perspectiva da moral.

Para além desse efeito grave da amoralização em geral, poderíamos falar ainda de uma série de injustiças e iniquidades dos ricos e poderosos contra os fracos, os pobres, os pequenos, num mundo que é já um pouco aquele que encontramos. Um mundo no qual, a partir de uma semelhante dinâmica, os ricos são sempre cada vez mais ricos e os pobres sempre cada vez mais pobres, onde os ricos e poderosos são sempre menos e os pobres são sempre mais numerosos, mais multidão.

A concorrência, por outro lado, dá cabo da fraternidade entre os homens. Converte o outro, qualquer outro, num obstáculo, num adversário, num inimigo a abater. Importa apenas abatê-lo se for possível sem fazer muito barulho. Vêmo-lo hoje tantas vezes nesta nossa sociedade. É a lei da selva que entra em vigor, "o homem lobo para o outro homem" de Hobbes. É um mundo de lobos que pode estar às nossas portas. Se calhar, ainda pior. Nunca se viu de facto, no mundo dos lobos, um lobo matar, comer outro lobo para sobreviver. Estamos com este nosso mundo da concorrência a criar um mundo de feras, um mundo mesmo selvagem. Não é sem razão que, no campo do desporto, onde a concorrência é a lei e escola, os nomes que designam ou identificam os maiores clubes ou pessoas do futebol falem de leões, dragões, águias, panteras e não sei que mais. A consequência está bem à vista nos campos de futebol ou às saídas dos estádios. Só a polícia e bem armada.

A concorrência torna impossível sobretudo o amor ao próximo, base e fundamento de toda a moral cristã. Por isso Nietzsche, cuja filisofia está subjacente a este modelo concorrencial, fala do cristianismo como filosofia da mediocridade, inimigo do progresso pelo facto de impor o amor ao próximo. Segundo ele tem de ser exactamente o contrário. Nada de falar do amor, mas do ódio ao próximo. Há que odiar o próximo, que é exactamente aquele que está ali, ao pé de mim, porque é precisamente esse que me impede de subir. No máximo, poderá falar-se do amor ao que está longe de mim, uma vez que esse não me impede propriamente a subida. Por isso mesmo, prossegue o mesmo Nietzsche, a moral tem uma medida e um critério. A sua medida é a crueldade. Só assim, continua ele, se vai chegar ao grande ideal do super-homem, ideal a conseguir sempre e só passando por cima do cadáver de todos os que vão fícando para trás. ${ }^{5}$

É por esta via da concorrência que se abrem assim os caminhos ao capitalismo selvagem de Stirner. Por tal motivo queria ele um mundo livre, sem estado, sem Igreja, sem autoridade, a fim de, mais facilmente, poder avançar nos seus caminhos do progresso que nunca pode ser o progresso de todos, mas apenas o progresso de alguns. 
Pelos caminhos da concorrência, à luz do que fica dito, podemos concluir que, nesta nossa sociedade, o fosso entre o mundo dos ricos e o mundo dos pobres vai ser sempre maior. Cada vez os ricos serão sempre mais ricos e os pobres serão sempre mais pobres. A justiça social, por seu lado, ficará cada vez mais sem qualquer hipótese. É que, em dado momento, vão ser os que mais vão crescendo à custa dos outros que controlarão sempre mais o estado e o mundo do poder e ocuparão os lugares de comando, mesmo nos países chamados democráticos. É que, até ali, serão eles que vão dispor de mais meios para comprar e manipular, de todas as maneiras, até e muito especialmente aqueles que os irão eleger e levar ao poder, mesmo que isso se venha a fazer sempre em eleições chamadas livres.

Porque é assim, a concorrência aparece condenada constantemente pelo Magistério da Igreja em termos claros e bem precisos, sobretudo quando ela é desenfreada, como acontece hoje e sempre mais. É o que podemos verificar na "Rerum Novarum" de Leão XIII ${ }^{6}$, na "Quadragesimo Anno" de Pio XI ${ }^{7}, \mathrm{Na}$ "Mater et Magistra" de João XXIII ${ }^{8}$, na "Populorum Progressio" de Paulo VI ${ }^{9}$ e também na "Centesimus Annus" de João Paulo II ${ }^{10}$, muito embora este último Papa não a considere tão directamente como o fizeram os seus predecessores.

Mas é sobretudo o Evangelho que exclue este modelo concorrencial e é o Evangelho propriamente que fala do tema que aqui me ocupa, perspectiva que passo agora a expor.

\section{O EVANGELHO E O MODELO CONCORRENCIAL}

Se há alguma coisa em contraste evidente com o Evangelho, ela é do modelo concorrencial, isto é, a pretensão de crescer, avançar sobre o outro, deixando-o para trás ou então passando por cima dele.

Contestou este modelo o próprio Cristo, antes de mais com o seu exemplo. Vindo para o meio dos homens, foi misturar-se com os mais pobres, os servos, os pobres de Javé, com os que ocupavam o último lugar. O presépio é bem um sinal disso ${ }^{11}$. Em criança, viu-se logo ameaçado, vítima de alguém que o considerava seu concorrente: o Rei Herodes. Por isso e só por isso o monarca quis logo liquidá-lo ${ }^{12}$. Para escapar ao furor da concorrência teve de fugir e exilar-se, logo em criança. $O$ critério de Jesus era exactamente o contrário da concorrência. Ensinou a pretender, não o primeiro lugar, mas o último ${ }^{13}$. Não andar à procura de ser o maior, mas o menor ${ }^{14}$. Condenou expressamente o modelo da concorrência , logo que ele se manifestou no grupo dos seus ${ }^{15}$. Privilegiou os últimos, os do último lugar: a mulher pecadora, na casa de Simão ${ }^{16}$, Mateus, os pecadores e os publicanos ${ }^{17}$, Zaqueu, com toda a má fama que levava consigo e as injustiças que o acompanhavam ${ }^{18}$. Levou para o céu, em primeiro lugar, um homem da pior espécie, um criminoso, um supliciado ${ }^{19}$. Repreendeu os seus discípulos pela 
discussão concorrencial, a inquirirem, em aberta altercação, qual deles seria o maior, aproveitando para lhes oferecer como critério de orientação na discussão que o maior era exactamente aquele que fosse o mais pequeno de todos ${ }^{20}$. No Sermão da Montanha proclamou bem aventurados os humildes ${ }^{21}$. Condenou a oração do fariseu que, até a rezar, queria situar-se à frente do publicano ${ }^{22}$. No Jardim das Oliveiras, mandou a Pedro meter a espada na bainha, quando ele se dispunha a concorrer, em defesa de Jesus, com os esbirros ${ }^{23}$.

Foi seguindo um Cristo que pensava assim, que Paulo excluía nos cristãos todas e quaisquer rivalidades ${ }^{24}$ e Francisco de Assis queria que os seus seguidores e irmãos se chamassem Irmãos, Frades Menores, como aqueles que estão sempre abaixo dos outros. No Evangelho, o critério é pois, não pôr-se à frente dos outros, mas atrás e abaixo.

Em relação a uma sociedade como a nossa, o cristianismo continua a ser por isso mesmo, ainda hoje, como nos tempos da primitiva Igreja, um ideal verdadeiramente subversivo. S. Paulo foi acusado exactamente desse crime: o crime da subversão ${ }^{25}$.

Com um modelo assim, porém, não se pense que Jesus, no seu Evangelho, não estimulasse o crescimento, no sentido de ser mais, de produzir mais. Ninguém como ele o soube fazer. Fê-lo, porém, seguindo outro caminho muito diferente, mas certamente mais eficaz. Não foi um caminho feito a olhar para o outro, vendo a forma de se pôr acima dele, sempre à frente dele. $O$ caminho apontado por Jesus foi o da responsabilidade, da resposta ao apelo constante de Deus a crescer sempre mais, a ser mais, a ser sempre uma melhor e mais perfeita imagem de Deus, a mostrar sempre, mais perfeita e adequadamente, o próprio Deus na vida, em toda a vida, a fazer render o mais possível os talentos que cada um recebeu de Deus e dos quais cada um deve dar-lhe rigorosas contas. É por aqui que vai o crescimento, o progresso, na linha do Evangelho. É em tal sentido que se deve entender a ordem terminante de Jesus, um dos seus mandamentos fundamentais: "sede perfeitos como Vosso Pai celeste é perfeito" ${ }^{26}$. Um tal ideal assim, voltado para um crescimento exigente e sem fim, não existe nem pode existir. Passa por aqui o destino, a vocação de todos à santidade, santidade que é o máximo da perfeição que se pode e deve atingir, a todos os níveis. De uma tal vocação, fala expressamente Paulo na Carta aos Efésios ${ }^{27}$, vocação que o Concílio Vaticano II sublinhou e propôs de novo em forma absoluta a todos os fiéis, sem excepção ${ }^{28}$. O mesmo pode dizer-se do apelo do Senhor a vivermos e actuarmos constantemente de modo que os outros vejam as nossas boas obras e glorifiquem o Pai que está nos céus ${ }^{29}$. É o sentido da parábola dos talentos, altamente significativa na perspectiva do que aqui estamos a dizer. Ali aparece condenado o servo, qualificado precisamente como mau, por ter escondido e enterrado o talento que lhe fora confiado, não o pondo a render ${ }^{30}$. O mesmo significado tem o louvor atribuído aos outros dois servos que, recebendo cada um talentos diferentes, os aproveitaram e, na propor- 
ção dos mesmos, os fizeram render ${ }^{31}$. As virgens loucas, da outra parábola de S. Mateus, foram condenadas só porque deixaram apagar as suas lâmpadas ${ }^{32}$. Na parábola da vinha e dos trabalhadores contratados, todos receberam a paga pelo trabalho prestado, sem atenção a quaisquer comparações e até excluindo-as expressamente ${ }^{33}$. Propõe-se certamente o olhar para o outro, não porém para concorrer, mas para aprender com ele ${ }^{34}$. Nunca para o ultrapassar e, muito menos, para o esmagar.

Foi com um ideal de crescimento e progresso assim que a humanidade, ao encontrar-se com o cristianismo, se desenvolveu e cresceu até na ordem da riqueza, da técnica, da civilização, como ainda hoje se pode verificar. Assim o reconheceu o próprio Max Weber ao explicar, a partir daqui, o facto de serem os países mais marcados pelo cristianismo que ainda hoje detêm no mundo a maior riqueza e o maior nível de desenvolvimento técnico-científico. Por isso está longe de ser verdade o que pretendeu afirmar Maquiavel ao dizer, em "O Príncipe", que, com a moral cristã, não se podem fazer grandes coisas. Quem há aí que tenha feito na humanidade e para a humanidade coisas maiores do que Jesus Cristo? Quem, mais do que Ele, marcou esta nossa história de 2000 anos? Ao falarmos de Jesus Cristo, poderíamos falar de tantos outros que foram e são figuras eminentes da sua escola. Recordemos apenas, a título de exemplo, Bento de Núrsia, nos períodos da implantação da Europa, Francisco de Assis, na Idade Média e no mundo que se lhe seguiu, Teresa de Calcutá, no nosso tempo, a nível da promoção social, o Padre Américo, junto dos jovens abandonados do Barredo e outros, o Padre Damião, com os seus leprosos, na Ilha de Molokai, os missionários de hoje e de sempre, etc. etc..

Vai por aqui, pelo evangelho de Jesus Cristo e por aqueles que o viveram e o vivem, muita luz que pode orientar os cristãos de hoje situados necessariamente neste mundo, que é o nosso. Mundo onde eles têm de viver e actuar, sempre em contraste entre a iluminação do Evangelho e a grande e perigosa tentação da concorrência. Num mundo assim, impõem-se atitudes que consideramos próprias de um cristão. É destas atitudes que, para concluir, agora me vou ocupar.

\section{ATITUDES CRISTÃS NUM MUNDO EM CONCORRÊNCIA}

Num mundo dominado pela concorrência, a qualquer preço, sem ética, sem olhar a consequências, torna-se extremamente difícil o viver cristão, sobretudo o viver cristão a corpo inteiro. Tentar fazê-lo é quase sempre expor-se ao esmagamento total. É por aqui sobretudo, como já se disse, que o Evangelho é uma grande utopia, no sentido etimológico do termo. Ao olharmos para os critérios de acção, para as motivações do mundo, dá impressão de nos encontrarmos nos antípodas do Evangelho. 
Entretanto, seja como for, o certo é que temos de viver num mundo assim. Temos de viver num mundo assim e, ao mesmo tempo, temos de ser cristãos. Sê-lo-emos com certeza e com a graça de Deus, se não esquecermos algumas atitudes, atitudes que apontarão sempre para os assim chamados mandamentos "meta" do Evangelho, como são designados pelos especialistas da Bíblia. Eles abundam no Evangelho, sobretudo no Sermão da Montanha de S. Mateus ${ }^{35}$.

Sublinharei apenas algumas dessas atitudes que poderão ser um belo programa, para sermos cristãos num mundo como o nosso e também para atenuarmos um pouco esta componente concorrencial nesta nossa caminhada civilizacional que mais parece uma marcha para a morte ou, na melhor das hipóteses, um retrocesso de volta à selva, ao coliseu das feras do império romano ${ }^{36}$. Tais alternativas poderão lançar um pouco de luz no meio das trevas em que nos movemos. Aponto-as, sem uma ordem rigorosamente lógica ou de importância, tais quais elas me foram ocorrendo numa reflexão pessoal.

A NÍVEL MORAL, haveria que promover a chamada dinâmica vocacional ou responsável de que fala o Concílio Vaticano II, sobretudo no "Optatam Totius" quando diz que a moral deve ter como objectivo fundamental mostrar a vocação do homem em Cristo ${ }^{37}$. Há que actuar, não com miras a avançar por cima do outro, a ser mais do que o outro, mas apenas e só para responder aos apelos, ao chamamento de Deus. Apelos que nos chegam nomeadamente a partir do íntimo da consciência que, em cada um de nós, é a voz de Deus a chamar-nos. É a tal moral da responsabilidade. Responsabilidade vem de responder.

Actuação, pois, responsável, vocacional. Actuação a partir de valores. Precisamos, todos temos necessidade de crescer. Só crescemos, porém, se o fizermos a partir de valores. Ninguém cresce só pelo mero facto de deixar o outro para trás, inutilizado, neutralizado ou morto.

A NÍVEL PEDAGÓGICO, torna-se necessário definir o êxito, a vitória não a partir do triunfo da pessoa que passa por cima seja de quem for, mas em ser mais, com base no que sou e no que tenho, pondo em acção e a render todas as qualidades ou dotes que possuo, os dons que recebi, dons e qualidades únicas e irrepetíveis. Neste sentido haverá que levar as pessoas a serem sempre mais, dando e oferecendo aquilo que cada um tem, aquilo que só aquela pessoa pode oferecer e recusar sempre a pretensão de esmagar seja quem for. Haveria que criar prémios na escola, no desporto, em quaisquer actividades, não apenas para aquelas pessoas que fazem coisas consideradas maiores ou mais importantes do que as dos outros, porque os ultrapassaram, porque os esmagaram. Pode suceder efectivamente que mesmo qualquer deficiente, num êxito simples que teve, possa e deva receber um prémio maior do que muitas pessoas escorreitas que talvez, mesmo ganhando grandes prémios, deixam neutralizadas outras qualidades ou possibilidades de que dispõem na riqueza da sua personalidade, a nível moral, espiritual, intelectual, etc. 
A NÍVEL DESPORTIVO E DE LAZER, é necessário não andarmos a entreter as pessoas, a formar jovens, estimulando-os e lançando-os, com os nossos prémios, na arte e habilidade de esmagar o semelhante, situando a vitória na perspectiva da luta que esmaga e deixa o outro humilhado, frustrado. Será que não temos imaginação para nos distrairmos a nós próprios e entretermos os outros, a não ser deixando vítimas atrás de nós? Bastar-nos-ia olhar um pouco para a natureza, que possivelmente ainda não degradámos, e dispormo-nos a aprender com ela. As fontes, as águas, os rios correm sem esmagar ninguém e é então que são belos. As ondas do mar vêm beijar os nossos pés, sem pretenderem, directa e intencionalmente, destruir ninguém. Os passarinhos cantam no meio do arvoredo sem intentos de ultrapassarem seja quem for. As flores exalam o seu perfume e mostram-nos a sua beleza, sem andarem a passar umas sobre as outras. As árvores do campo vão-nos dando sempre os seus frutos, sem destruírem ninguém. Será que só o homem está feito para a destruição, para encher de vítimas o seu caminho, até quando vai ou ensina a brincar?

A NÍVEL ECONÓMICO, haverá que criar incentivos, não para atropelar o semelhante, mas para que cada um no seu trabalho e actividade renda sempre o mais que puder. Será necessário consegui-lo, a partir nomeadamente da colaboração que queremos e devemos prestar a Deus que, por nosso intermédio, quer prosseguir a obra da criação que Ele mesmo nos confiou para a completarmos. A partir igualmente do dever de colaborarmos sempre mais na felicidade de todos os homens esforçando-nos, cada um do seu lado, para que a ninguém falte o pão de cada dia, uma habitação condigna, condições de vida sempre mais dignas do homem, como imagem de Deus. Poderá também apontar-se a esperança de recebermos um dia a recompensa prometida pelo Senhor que nos garante não deixar sem retribuição nem sequer um copo de água fria que dermos, em seu nome, a quem quer que for. ${ }^{38}$

A NÍVEL EVANGÉLICO, é urgente fazermos todos uma opção preferencial, verdadeira e coerente pelos pobres, pelos deficientes, pelos marginalizados da sociedade, por todos os que ficaram para trás. Será necessário para isso irmo-nos misturar com eles, como fez Jesus e, depois dele, tantos outros que o seguiram mais de perto, tais como Francisco de Assis, João de Deus, o Padre Américo, Teresa de Calcutá, Luter King, Gandhi, os missionários de hoje e de sempre, etc. etc.. Temos de ver como acabar com o gravíssimo escândalo de $1 / 5$ dos homens andarem a crescer neste nosso mundo à custa de $4 / 5$ da humanidade ${ }^{39}$.

A NÍVEL DA HISTÓRIA, haverá que aprender a dimensioná-la de outra maneira. Torna-se necessário avaliar, com sentido mais crítico, as figuras da história que temos andado a imortalizar, ao celebrarmos e cantarmos como heróis tantas pessoas que outra coisa não fizeram senão oprimir, destruir o seu semelhante, pessoas que deixaram, atrás do seu "heroísmo", montes de cadáveres, de homens como nós, com o direito de viverem, pessoas que só subiram a esmaga- 
rem o seu semelhante. Teremos possivelmente de repensar neste sentido muitos monumentos que levantámos, não seja que andemos a imortalizar criminosos da pior espécie e os propunhamos depois desgraçadamente aos jovens como modelos na construção do nosso mundo.

A NIVEL SÓCIO-POLÍTICO, o critério terá de ser, não o subir mais fácil e rapidamente os degraus do poder ou do comando, seja a que preço for. $O$ critério deverá ser sempre e só a promoção e defesa dos direitos fundamentais da pessoa humana, de todos e cada um dos homens, a sua dignidade, sempre inviolável e sagrada. Haverá que constituir como aferidor, de sentido absoluto, em todos os processos, a justiça social. Justiça social que tem necessariamente como objectivo temperar sempre de novo os rendimentos dos que avançam por cima dos outros, fazendo que, pelo menos parte dos seus lucros exagerados vá ajudar um pouco mais aqueles que, possivelmente eles mesmos, com as suas injustiças, deixaram para trás. Importa que, tanto quanto possível, todos cresçamos juntos, não esquecendo nunca que todos pertencemos à mesma família humana e que os bens que existem sobre a terra foram criados e são destinados a todos os homens sem excepção. Haverá que formular leis e criar instituições sempre com este mesmo critério nos nossos parlamentos, na nossa governação. É para isso que os políticos estão no poder. Sempre que não tiverem ou não forem capazes de um tal programa, o melhor que fazem é dar lugar a outros que o desejem, possam e queiram realizar. Nasceram nestes últimos anos 7000 organizações voltadas para a solidariedade, a nível político, comercial, cultural, religioso, etc. ${ }^{40}$. Está bem mas é urgente que elas funcionem.

A NÍVEL DO PROGRESSO E CRESCIMENTO, é indispensável que haja normas, que exista ética, de modo a impedir-se que os lobos e as panteras andem à solta, em liberdade. Só assim é que o progresso não se converterá em retrocesso, retrocesso ameaçador para pessoas e povos.

A NIVEL DA INFORMAÇÃO, haverá que pôr fim, o mais rápido possível, nomeadamente nos grandes meios de comunicação social, à promoção, glorificação e aplauso dos que vivem e prosperam à custa da desgraça ou destruição dos outros, dos exploradores dos fracos, dos opressores e tiranos que barram o caminho de tantos que querem e também têm o direito de viver, de caminhar na vida, que também querem e têm o direito de respirar. Teremos de terminar com os aplausos a todos os êxitos e vitórias dos que triunfaram, destruindo os seus colegas de viagem, da grande viagem da vida que deve ser vida para todos.

A NÍVEL DA EVANGELIZAÇÃO, ter-se-á de anunciar mais e sempre mais alto e sempre com maior força, com maior coragem, destemidamente, o mandamento do amor. Do amor sobretudo ao próximo, ao irmão que está aí ao lado, nos mil caminhos que descem de Jerusalém para Jericó ${ }^{41}$. O mandamento do amor que é sempre também o mandamento do serviço a todos traduzido da melhor maneira no exemplo do Senhor, de joelhos, a lavar os pés aos seus discípulos, em 
Quinta-Feira Santa ${ }^{42}$. Serviço que é sobretudo e sempre serviço aos mais pequenos, aos mais pobres, aos menos capazes, levando-os sempre pela mão na subida, ao encontro da vida e ao encontro de Deus, encontro a que eles e todos nós estamos chamados por vocação. Há que levá-los a todos, sem excepção. Pode parecer a alguns que assim subimos menos. Será verdade mas, em qualquer dos casos, subiremos todos e, quando subimos todos, subimos mais e subimos certamente melhor. Não podemos esquecer, como ensinou João Paulo II, que a solidariedade é um princípio axiológico na Igreja e em todo o comportamento que for verdadeiramente humano ${ }^{43}$. É só na solidariedade que poderemos salvar e defender os mais pequenos, os mais fracos ${ }^{44}$. Por isso mesmo é que a solidariedade faz parte da missão evangelizadora da Igreja ${ }^{45}$. É a tal ética, a tal economia de comunhão de que hoje se fala ${ }^{46}$, ética e economia que requer, como é evidente, antes de mais, a desmontagem da avareza ${ }^{47}$.

\section{CONCLUSÃO}

Num mundo dominado por uma concorrência desenfreada, sinto que este discurso, nos termos em que o fiz, é um grande sonho. Não tem sentido. Pode ser uma loucura. Talvez seja um escândalo. Era já assim o Evangelho que Paulo pregava na igreja de Corinto ${ }^{48}$. Nesta reflexão que fiz, é natural que até me chamem ingénuo, poeta ou sonhador. Entretanto, num mundo sem encanto, como já o definiu Max Weber, é bom que alguém tenha coragem de apelar ao sonho, ao encantamento do mundo, ao tempo auroral, de que fala uma das nossas escritoras contemporâneas ${ }^{49}$. Sem uma certa dose de sonho e de utopia, vai ser difícil, quase impossível haver futuro, tendo em conta tantos e tão poderosos meios que aí estão a chegar para se ultrapassar, para se barrar o caminho da maioria dos homens. $\mathrm{E}$, não podemos esquecer que, quando a maioria não tiver futuro, a mais curto ou longo prazo, ninguém certamente vai ter futuro.

Não posso deixar de referir que há também uma forma positiva de olhar para o outro que sobe na vida à nossa frente. Tal forma positiva de olhar para o outro que sobe, será sempre e só quando, ao olharmos para ele, crescermos nós também, a partir da luz que irradia do bem e da grandeza que transparecem no irmão que vai à nossa frente. Nesse momento, não se trata já de irmãos degenerados que barram o caminho dos que vêm atrás. Serão estrelas a brilhar no caminho dos homens, na sua subida, que ajudam e estimulam os outros a subirem e a subirem sempre mais. É o tal exemplo, o bom exemplo, a que se faz também apelo no Evangelho ${ }^{50}$.

Para ser possível uma cruzada assim, 6 condição indispensável que todos nos disponhamos a combater a nova espécie de sida a que, há pouco tempo, se referia João Paulo II. Sida que consiste na deficiente imunidade de vícios e hábitos pessoais e sociais que corrompem e ameaçam os grandes valores do Evangelho e da 
humanidade ${ }^{51}$. Pode ser que um tal género de sida seja ainda mais ameaçador do que a sida que hoje ameaça e enche de pavor tanta gente. Pode ser muito bem que também esta nova espécie de sida esteja na origem desse flagelo que aí anda a ameaçar a humanidade.

Vai um pouco por aqui a construção da nova terra e dos novos céus que todos desejamos e que alguém deve começar. Deveríamos ser todos dessa gente que começa, que tem a ousadia de pertencer aos cabouqueiros do mundo novo que queremos seja o mundo de todos nós.

\section{NOTAS}

1. Gen 3,5.

2. IOANNES PAULUS II, Litterae Encyclicae "Redemptor Hominis", em AAS 71(1979) 283.

3. S. THOMAS, S. Theologica, II-II, 90,4; VIDAL, M., Moral de actitudes, vol. I, 3 ed., Ed. PS, Madrid, 1975, p. 271.

4. Cfr. MARCUSE, H., El hombre unidimensional (trad. esp.), Barcelona 1969. 1978.

5. Cfr. NIETZSCHE, F., Das Ressentiment im Aufbau der Moralen, Klostermann, Frankfurt,

6. LEONE XIII, "Lettera enciclica "Rerum Novarum" sulla condizione dei lavoratori", n. 2, (trad. it.), em I Documenti sociali della Chiesa, ed. Massimo, Milano 1983, p. 100

7. PIUS XI, Litterae Encyclicae "Quadragesimo anno", em AAS 22 (1931), 211.

8. IOANNES XXIII, Litterae Encyclicae "Mater et Magista" em AAS 53 (1961), 404.

9. PAULUS VI, Litterae Encyclicae "Populorum Progressio" em AAS 59 (1967).

10. IOANNES PAULUS II, Litterae Encyclicae “Centesimus annus", AAS 83 (1991), 844.

11. Lc 2,16

12. Mt 2,16

13. Lc 14,8

14. Mt 20,26

15. Mc 9,34

16. Lc 7,37

17. Mt 9,10

18. Lc 19,7

19. Lc 23,43

20. Mt 20,25 
21. Mt 5,5

22. Lc 18,14

23. Jo 18,11

24. Fil 3,5

25. Act 21,$28 ; 24,5$

26. Mt 5,48

27. Ef 1,4

28. Lumen Gentium, 39

29. Mt 5,16

30. Ibidem, 25,26-30

31. Ibidem, 25, 20-30

32. Ibidem, 25,3-12

33. Ibidem, 20,8-16

34. Ibidem, 5,16

35. Ibidem, 5-7

36. ANGULO A., "Contra a guerra, a solidariedade", em Brotéria, 137 (1993), n 1, 6.

37. Optatam Totius, n. $^{\circ} 16$

38. Mt 10,42

39. Cfr. CONCI A., "I valori degli europei fra evoluzione e nostalgia", em Rivista di teologia Morale, 97 (1993), 72.

40. LORENZETTI L., Il potere politico mondiale, ibidem, p. 37.

41. Lc 10,30 .

42. Jo $13,1-17$

43. IOANNES PAULUS II, Litterae Encyclicae "Centesimus annus", AAS 83 (1991) 805.

44. Idem, Ibidem, 813

45. Idem, Sitterae Enciclicae "Sollicitudo sei socialis", AAS 80 (1988), 570.

46. BOF G., "L'annuncio di un sinodo delle due Americhe", em Rivista di Teologia morale, 97 (1993). 22.

47. ANGULO A., ob. cit., p. 9.

48. 1 Cor 1,23 .

49. Cfr. DA COSTA, L., Na Água do Tempo, Ed. Quimera, Lisboa 1992, 14-16.

50. Mt 5,16.

51. GIOVANNI PAOLO II, "Discorso ai participanti alla conferenza internazionale promossa dal Pontificio consiglio per la pastorale, degli operatori sanitari", em L'Osservatore Romano, 17 novembre 1989, 4. 